\begin{tabular}{l}
\hline Jurnal Pakarena \\
Volume 4 Nomor 1, Juni 2019 \\
e-ISSN: 2550-102X dan p-ISSN: 1693-3990 \\
\begin{tabular}{|l|l|l|}
\hline (1) This work is licensed under a Creative Commons Attribution & PAKARENA \\
\hline
\end{tabular}
\end{tabular}

\title{
PENINGKATKAN KETERAMPILAN OLAH GERAK YANG KONTRIBUTIF TERHADAP PRESTASI MAHASISWA PRODI SENI TARI DENGAN OPTIMALISASI PERANAN SANGGAR TARI
}

\section{Rahma M}

Keywords :

Peningkatan; Peranan; dan

sanggar tari.

\section{Corespondensi Author}

Seni Pertunjukan, Universitas

Negeri Makassar, Fakultas Seni

dan Desain Jln. Dg. Tata

Kampus UNM Parangtambung

satriadi@unm.ac.id

\begin{abstract}
ABSTRAK
Peningkatan keterampilan olah gerak dalam menarikan tari tradisional, kreasi baru (koreografi) bagi mahasiswa, terlebih tari tradisional dan koreografi menjadi salah satu mata kuliah yang terdapat pada kurikulum seni tari di dukung dengan kehadiran sanggar sebagai wadah untuk mengasah skill di luar kelas formal. Sanggar dengan fungsi utama sebagai pelestari tari tradisional sudah barang tentu lebih fokus pada pelatihan dan pengembangan tari tradisional, terlebih permintaan konsumen sanggar juga lebih ke tari tradisional baik tari tradisi yang telah ada maupun tari kreasi baru.

Prestasi mahasiswa yang tergabung dalam sanggar ditandai dengan banyaknya mahasiswa yang sering menjuarai lomba tari yang dilaksanakan oleh instansi lain, dan ini juga nampak pada nilai ujian dalam hal praktek atau keterampilan olah gerak dalam menarikan suatu tarian, serta menata atau menciptakan tari kreasi baru. Hal ini tidak terlepas dari peran sanggar yang telah memberi ruang bagi mahasiswa tari yang tergabung sebagai anggota sanggar untuk berkreasi dan berinovasi.
\end{abstract}

\begin{abstract}
Studio with a primary function as a preserver of traditional dance is of course more focus on training and development of traditional dance especially consumer demand studio is also more to the traditional dance of good dance traditions that have been there and dance new creations, this is of course an impact on improving the skills of dance dance traditional first dance for students traditionally been one of the subjects included in the curriculum of dance.

Achievement of students joined in the studio is marked with the number of students who often win the dance contest held by other institutions, and also appears in the value of the test in terms of practice or the navigation skills in dancing a dance, as well as to organize or create new dance creations. It is inseparable from the role that the studio has provided room for dance students who joined as a member of the studio for creativity.
\end{abstract}


Rahma, M, Peningkatkan Keterampilan Olah Gerak Yang Kontributif terhadap prestasi mahasiswa Prodi Seni Tari Dengan Optimalisasi Peranan Sanggar Tari, hlm. 36-43

\section{PENDAHULUAN}

Ketimpangan yang terjadi pada dunia pendidikan kita, yang cenderung lebih menekankan pada aspek kognitif dan bermuara pada kecerdasan intelektual semata, mangakibatkan kecerdasan emosional serasa terpinggirkan. Kecerdasan intelektual semata hanya akan melahirkan manusia robot, sumber daya manusia yang tidak punya ruh maupun karakter, manusia terampil yang kering etika, moral, dan spiritual, serta melahirkan manusia yang berpikiran pragmatis dan berselera instan, dalam arti mencari sesuatu dengan cara relative mudah dengan jalan pintas, cepat dinikmati dan cepat pula dibuang. Atas dasar inilah kecerdasan intelektual perlu diimbangi dengan kecerdasan emosional dalam hal ini melalui pendidikan seni khususnya seni tari sebagai pendidikan (pembelajaran) nilai. (Jazuli, 2008:2)

Seni Tari adalah salah satu cabang seni yang hidup dan berkembang di Indonesia. Keberadaannya merupakan salah satu kekayaan bangsa yang mempunyai kedudukan tersendiri dihati masyarakat pendukungnya. Dalam penyajiannya seni tari bisa dikategorikan seni yang kompleks karena merupakan perpaduan seni gerak, musik, teater dan rupa. Pada dasarnya keempat elemen ini memiliki perbedaan yang mendasar khususnya jika ditinjau dari sisi instrument utamanya, akan tetapi ketika dipadukan akan menjadi satu bentuk pertunjukan yang luar biasa.

Pertunjukan merupakan usaha sadar mempertontonkan, tetapi apa yang dipertontonkan dalam pertunjukan tari, apakah kecantikan penarinya? Apakah keluwesan penari dalam bergerak? Ataukah kemewahan dan keindahan artistiknya? Jawaban-jawaban ini memiliki signifikansi yang beragam pula. Namun, yang jelas bahwa pertunjukan merupakan jalinan gerak, musik, atribut visual yang datang berbarengan dan berkesinambungan membawa sentuhan rasa, ekspresi, dan wujud (bentuk). (Wahyudiyanto,2009;19). Hal ini menjadi kompetensi yang harus dimiliki oleh mahasiswa seni tari.

Agar mahasiswa dapat mencapai kompetensi tersebut perlu dilatih dan dibimbing dengan kegiatan seni yang mengarah kepada kemampuan dan keterampilan menyajikan bidang seni yang diminati diantaranya adalah tari, dan hal ini dapat tercapai jika mahasiswa memiliki kemampuan yang maksimal dalam mengolah gerak sehingga mampu membawakan sebuah tari dengan baik, baik dalam menarikan tari tradisional maupun kreasi seperti halnya sedang berbicara dengan orang lain.

Bertolak dari hal tersebut diatas, maka kegiatan penelitian ini berupaya untuk memberikan pendekatan yang dapat membantu dalam hal pemahaman pengetahuan dan peningkatan keterampilan mahasiswa seni tari. Pendekatan yang dimaksud adalah bagaimana mengoptimalkan peran sanggar dalam mengasah keterampilan anggotanya yang juga merupakan mahasiswa tari pada prodi Seni Tari. Prodi Seni Tari merupakan salah satu program studi pada Fakultas Seni dan Desain UNM yang mendidik mahasiswa untuk memahami, melestarikan dan mengembangkan tari daerah setempat dan nusantara serta kreasi baru, artinya pada prodi ini mahasiswa dituntut untuk menguasai seni tari baik secara teoritis maupun paraktek. Pada praktek tari mahasiswa harus mampu menarikan berbagai macam tari daerah setempat maupun nusantara dan juga harus mampu untuk berkreasi dan inovatif. Untuk itu penting untuk mengeksplorasi peran sanggar sebagai sarana pendukung atau penunjang kegiatan bimbingan edukatif diluar kelas.

\section{METODE}

\section{Jenis Penelitian}

Sebagai penelitian kualitatif, sumber data yang digunakan yaitu: sumber tertulis, lisan, dan dokumentasi. Sumber data pada penelitian Peranan sanggar tari dalam meningkatkan keterampilan olah gerak yang kontributif terhadap prestasi mahasiswa pada prodi Seni Tari FSD UNM diperoleh dari sumber primer dan sekunder. Dengan demikian demikian penelitian ini menggunakan pendekatan dengan multi disiplin, yakni pendekatan psikologis, sosiologis, dan antropologis. Pendekatan multi disiplin bukan hanya terbatas pada analisisnya, akan tetapi juga pada pencarian dan pengumpulan datanya.

Untuk melengkapi data penelitian diperlukan sumber data dengan metode: 1). Studi pustaka yang bertujuan untuk mencari 
data akurat tentang objek penelitian dan mencari konsep-konsep teori yang dapat digunakan untuk membahas permasalahan melalui seleksi tulisan atau buku-buku yang mendukung objek penelitian, 2). Observasi untuk memperoleh data melalui penjajakan objek penelitian, 3). Wawancara untuk mendapatkan data yang aotentik dan kredibel. Wawancara bukan hanya dilakukan dengan objek penelitian melainkan dengan informan dan narasumber yang lain, 4). Dokumentasi, yaitu melakukan kaji dokumen berupa buku catatan harian jika ada, agenda kegiatan dan ataupun photo yang buat sendiri ataupun dokumentasi

\section{Variable}

Berdasarkan tujuan penalitian yang akan dicapai, maka dikemukakan beberapa variable tentang Peranan sanggar tari dalam meningkatkan ketrampilan olah gerak yang kotributif terhadap prestasi mahasiswa yang dikaji berdasarkan pendekatan dan alur pikir sebagai berikut:
a. Pendekatan peranan dengan penekanan:
1. Fungsi
2. Penyesuaian diri
3. Proses

b. Kerangka pikir:

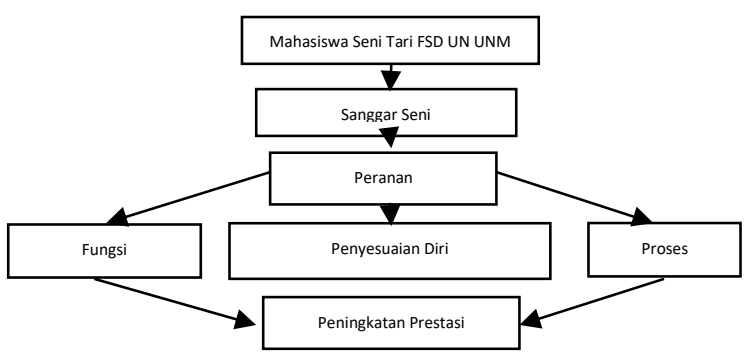

\section{Definisi Operasional Variabel}

Dalam pembahasan sebelumnya telah dikemukakan mengenai variable yang telah diteliti, oleh sebab itu untuk mempermudah tercapainya tujuan yang diharapkan pada penelitian ini maka perlu dijelaskan variablevariabel tersebut sebagai berikut:

a. Peranan sanggar dalam menunjang prestasi mahasiswa, yang dimaksudkan dalam hal ini adalah bagaimana sanggar melaksanakan pelatihan atau memprogramkan kegiatannya sehingga dapat membantu secara tidak langsung pengasahan dan peningkatan skill atau keterampilan mahasiswa yang tergabung dalam sanggar.

b. Prestasi mahasiswa dalam hal keterampilan olah gerak, yang dimaksudkan adalah bagaimana peningkatan keterampilan olah gerak mahasiswa yang tergabung dalam sebuah sanggar tari.

\section{HASIL DAN PEMBAHASAN}

\section{A. Hasil Penelitian}

Pada Sub Bab ini dijelaskan tentang peranan sanggar dalam meningkatkan keterampilan olah gerak yang kontributif terhadap prestasi mahasiswa pada Prodi Seni Tari FSD UNM. Lembaga pendidikan merupakan merupakan salah satu wadah yang paling mendasar dan paling efektif untuk mengenalkan budaya dan tradisi masingmasing daerah. Apabila lembaga pendidikan saja tidak mengenalkan budaya-budaya dan seni setempat khususnya seni tari mungkin generasi muda tidak mengenal seni tari dan menyukainya. Namun permasalahan tersendiri dalam dunia pendidikan formal sebab semua kegiatan dibatasi oleh waktu dan sejumlah mata kuliah yang harus dilalui oleh mahasiswa baik toeri maupun praktek, sehingga terkadang mata kuliah berakhir sementara mahasiswa belum sepenuhnya menguasai, dan kehadiran sanggar seni sebagai lembaga pendidikan non formal perlu diapresiasi.

\section{Aktifitas sanggar}

Sanggar-sanggar di Kota Makassar dalam menjalankan fungsinya sebagai pelestari tari tradisisonal dan kreasi daerah juga sebagai wadah untuk menyalurkan bakat minat bagi siapapun yang senang dan suka dengan bidang seni tari terlebih bagi mahasiswa dari prodi seni tari yang notabene aktivitas pembelajarannya tidak jauh dari dunia seni tari, merasakan bahwa kehadiran sanggar tentu saja sangat menguntungkan dan menarik minat mereka terlebih dengan bergabung dalam sanggar juga menguntungkan dari sisi ekonomi meskipun tidak begitu besar.

Rata-rata sanggar di kota Makassar, yang saat ini terus bertambah dan semakin menjamur, tetap tidak kehabisan lahan atau dengan kata lain masing-masing memiliki market atau pasar tersendiri, sehingga meskipun jumlahnya banyak tetapi setiap sanggar tetap saja memiliki frekwensi pertunjukan (job) yang tinggi atau sering. Dengan sendirinya situasi ini 
Rahma, M, Peningkatkan Keterampilan Olah Gerak Yang Kontributif terhadap prestasi mahasiswa Prodi Seni Tari Dengan Optimalisasi Peranan Sanggar Tari, hlm. 36-43

'memaksa' anggotanya untuk terus berlatih dan memperbanyak perbendaharaan tari sebagai modal untuk melayani permintaan pemakai jasa pertunjukan tari. Hal ini memiliki efek lain, yakni dapat membantu mahasiswa yang tergabung dalam sanggar untuk terampil mengolah gerak dalam menarikan sebuah karya tari.

Sanggar dengan fungsi utama sebagai pelestari tari tradisional lebih sudah barang tentu lebih fokus pada pelatihan dan pengembangan tari tradisional terlebih permintaan konsumen sanggar juga lebih ke tari tradisional baik tari tradisi yang telah ada maupun tari kreasi baru, hal ini tentu saja berdampak pada peningkatan keterampilan menarikan tari tradisional bagi mahasiswa terlebih tari tradisional menjadi salah satu mata kuliah yang terdapat pada kurikulum seni tari.

Aktifitas pelatihan tari pada sanggar 'intensitasnya lebih' dibanding di kampus hal ini memungkinkan keterampilan gerak mahasiswa yang tergabung dalam sanggar lebih terasah dan hal ini dapat menunjang peningkatan keterampilan gerak mahasiswa. Kurikulum pada program Seni Tari tentu saja berbeda dengan sanggar sebab di kampus selain diberikan mata kuliah praktek juga mahasiswa diharuskan mengikuti mata kuliah teori dengan bobot yang sama sedang di sanggar lebih fokus pada pelatihan kaitannya dengan penguatan keterampilan olah gerak dalam menarikan sebuah tari. Selain itu dari sisi referensi tari yang dimiliki oleh anggota sanggar juga lebih banyak dan seringnya melakukan performance di sanggar akan melatih dan menumbuhkan sikap percaya diri mahasiswa sehingga berdampak pada saat mengikuti perluliahan di kampus.

\section{Prestasi Mahasiswa yang tergabung dalam sanggar}

Peningkatan keterampilan menari atau mengolah gerak dalam menarikan sebuah tari pada mahasiswa yang tergabung dalam sanggar terasah tanpa mereka sadari merupakan efek dari latihan yang terus menerus di sanggar karena permintaan akan tari tradisi pada sanggar yang intensitasnya tinggi dibanding jenis tari lain, meskipun rata-rata sanggar hanya melakukan latihan bila ada permintaan mengisi acara. Selain memiliki Keterampilan olah gerak yang baik, mahasiswa yang tergabung dalam sanggar akan lebih mudah dalam mengerjakan tugas kaitannya dengan penggarapan sebuah karya tari. Kemudahan dalam penggarapan karya tari ini disebabkan, karena mahasiswa yang tergabung dalam sanggar sudah terbiasa melakukan hal tersebut. Hanya saja terkadang yang menjadi kendala adalah jadwal pertunjukan yang bersamaan waktunya dengan jadwal perkuliahan dan ini membutuhkan sikap bijak dari mahasiswa untuk memilih bahwa sebagai mahasiswa hal mana yang harus lebih diproritaskan.

Prestasi mahasiswa yang tergabung dalam sanggar ditandai dengan banyaknya mahasiswa yang sering menjuarai lomba tari yang dilaksanakan oleh instansi lain, dan ini juga nampak pada nilai ujian dalam hal praktek atau keterampilan olah gerak dalam menarikan suatu tarian, serta menata atau menciptakan tari kreasi baru. Hal ini tidak terlepas dari peran sanggar yang telah memberi ruang bagi mahasiswa tari yang tergabung sebagai anggota sanggar untuk berkreativitas.

Prestasi mahasiswa yang tergabung dalam sanggar sangat nampak pada Keterampilan olah gerak mahasiswa dalam menarikan sebuah tari, baik secara teknik maupun hafalan. Selain itu kemampuan mahasiswa yang tergabung dalam sangar juga tergambar pada saat proses penggarapan sebuah karya tari yang menjadi tugas pada salah satu mata kuliah, mahasiswa yang tergabung dalam sanggar lebih cermat dan mampu menggarap lebih baik, walau demikian bukan tanpa kendala khususnya dalam hal membagi waktu antara menjalankan aktivitas sanggar dan kampus. Namun kondisi ini jika dapat diatur dan diatasi dengan baik tentu saja tidak akan menjadi persoalan, dan sejauh ini mahasiswa pada Prodi Seni Tari dapat mengatasi masalah tersebut sehingga sebagaian besar mahasiswa yang tergabung dalam sanggar dapat selasai tepat waktu dengan nilai yang baik dan memuaskan.

\section{B. Pembahasan}

Sanggar sebagai wahana berkumpulnya orang-orang yang memiliki minat yang sama dalam hal ini tentu saja sangat membantu terlebih dalam hal menumbuhkan rasa percaya diri anggotanya sebab setiap sanggar memiliki perencanaan dan perancangan pelatihan yang berbeda namun, karena sanggar memiliki tujuan utama untuk dikenal oleh masyarakat luas jadi sudah barang tentu setiap saat berusaha hadir 
ditengah-tengah masyarakat sebagai pengisi acara (eksis). Dengan frekwensi pertunjukan yang tinggi tentu saja setiap sanggar menjadwalkan pelatihan yang sering pula, meskipun terkadang ada sanggar yang menjadwalkan kegiatan rutin pelatihan dan ada pula yang berlatih hanya pada saat ada kegiatan. Untuk mengetahui sejauh mana kontribusi sanggar dalam menunjang prestasi mahasiswa dapat ditinjau melalui pendekatan fungsi, penyesuaian diri, dan proses.

\section{Fungsi}

Sanggar dengan fungsi utama sebagai pelestari seni-seni tradisi, demikian juga halnya dengan sanggar-sanggar yang ada di kota Makassar tentu saja memiliki tujuan utama yang sama diluar tujuan lainnya sebagai penunjang perekonomian pemilik dan anggotanya. Saat ini geliat sanggar di kota Makassar memang sangat menonjol bahkan dapat dikatakan bahwa sanggar sekarang ini sangat menjamur, hal ini terjadi karena keterlibatan industri pariwisata dalam mensupport kehadiran sanggar-sanggar baru, sehinggar sanggar tari baru terus bermunculan. Kehadiran sanggar tari yang menjamur dikota Makassar memang terasa sangat bermanfaat karena itu berarti akan banyak wadah pelestarian budaya khususnya seni tari, dan hal ini juga menjadi magnet tersendiri bagi mahasiswa seni tari.

Mahasiswa seni tari yang memang membidangi tari tentu saja merasa sangat terbantu dengan kehadiran sanggar sebab sanggar akan menjadi salah satu tempat atau wadah untuk meyalurkan bakat dan talenta mereka, hanya saja yang menjadi persoalan adalah mental berkesenian memang masih terus menjadi pekerjaan rumah tersendiri kaitannya dengan mutu karya di sanggar dan prestasi mahasiswa yang aktif di sanggar.

Mutu karya dan prestasi mahasiswa, dua hal yang memang perlu dieksplorasi saat ini. Kecenderungan tari sanggar yang tidak lagi pada tataran seni melainkan komoditi, sejatinya tidak terlalu benar, sebab tipikal tari tradisi adalah paket tari etnik yang bisa dipelajari sebagai bahan pencetak generasi penari handal dan secara tidak langsung jika hal ini menjadi perhatian pada sanggar akan berefek pada prestasi mahasiswa yang tergabung dalam sanggar. Sehingga fungsi sanggar sebagai tempat pelestarian seni tradisi dapat terpenuhi dan sekaligus dapat berkontribusi terhadap akademik mahasiswa yang tergabung dalam sanggar.

Tidak dapat dipungkiri dewasa ini sebagian besar sanggar hanya mementingkan komoditi di banding mutu, dengan berbagai alasan teknis latihan rutin tidak dilakukan dan hanya melakukan pelatihan pada saat menjelang pertunjukan, walaupun masih ada yang melakukan latihan rutin itupun hanya beberapa sanggar diantaranya Sanggar Seni Katangka di Sungguminasa dan Yayasan Angin Mammiri (YAMA) Makassar dalam bentuk pelatihan atau kursus tari bagi masyarakat umum, dan beberapa sanggar lain meskipun jumlah sanggar yang hanya melakukan latihan menjelang pertunjukan masih lebih banyak, pada hal latihan rutin itu penting untuk melatih tehnik tari anggota sanggar sehingga memudahkan ketika ada permintaan (job) secara mendadak dan ini tentu saja juga berdampak pada keterampilan gerak seorang penari. Selain itu dengan keterampilan gerak yang mumpuni akan memudahkan ketika ada permintaan tari baru (kreasi), dan yang paling penting hal ini akan berdampak pula pada prestasi mahasiswa yang tergabung di sanggar dalam hal kerampilan olah gerak, sebab di sanggar anggotanya hanya memikirkan materi yang berhubungan dengan gerak tari tanpa perlu memikirkan terlalu banyak materi lain seperti halnya di pembelajaran kelas formal.

Tidak dapat dipungkiri berbicara tentang sanggar terkadang memunculkan pemikiran apakah sanggar yang berkontribusi terhadap prestasi mahasiswa atau sanggar justru diperkuat oleh mahasiswa tari yang telah dibekali ilmu secara teori dan praktek di kampus, namun demikian hal tersebut tidak penting untuk dipertentangkan sebab pada dasarnya keduanya saling membutuhkan, sebab sanggar membutuhkan mahasiswa tari sebagai penari yang sudah memiliki dasar dan penari membutuhkan sanggar sebagai tempat untuk mengasah bakat kaitannya jam terbang atau frekwensi untuk melakukan pertunjukan atau perform lebih tinggi sehingga dengan sendirinya mahasiswa akan mahir dalam praktek tari (menari) dan mempersiapkan diri sebelum perform. Selain itu, sanggar memungkinkan untuk lebih banyak mempelajari jenis tari karena memang fokus sanggar hanya pada pengasahan keterampilan dan pemberian referensi tari yang banyak untuk 
mengakomodir permintaan konsumen atau pemakai jasa sanggar tari.

Sanggar tari merupakan pusat dari kegemilangan seni dan moral, maka sudah seyogyanya diperhatikan dan dimanfaatkan segala potensi termasuk mewujudkan fungsi sanggar secara maksimal serta melatih skill penari dengan baik, sebab bila area ini dioptimalkan, dapat dipastikan penari hiburan, penari profesional, dan seniman tari akan 'hadir' serta akan berdampak pada prestasi mahasiswa yang dengan sendirinya akan memicu bermunculannya seniman tari intelektual.

\section{Penyesuaian diri}

Penyesuaian diri merupakan suatu proses dinamis yang bertujuan untuk mengubah perilaku individu agar terjadi hubungan yang lebih sesuai antara individu dengan lingkungannya. Hal inipun dapat terjadi pada sanggar dan kebutuhan mahasiswa tari yang juga sekaligus anggota sanggar mengingat kepentingan sanggar dan mahasiswa tari tidak jauh berbeda. Sanggar membutuhkan penari dengan keterampilan tari yang baik sementara mahasiswa tari dengan keterampilan olah gerak yang baik akan berdampak pada prestasi terutama dalam hal pembelajaran praktek tari.

Penyesuaian diri sanggar dapat ditempuh dengan melakukan komunikasi dengan anggota terutama yang masih berstatus mahasiswa sebab, selain harus aktif di sanggar mahasiswa juga harus mempertimbangkan dan memikirkan status sebagai pelajar yang memiliki tanggung jawab lain. Tidak dapat dipungkiri banyak mahasiswa yang aktif menjadi penari pada sebuah sanggar justru gagal dalam pendidikan hal ini terjadi karena tidak ada keseimbangan antara keduanya. Kehidupan di sanggar yang lebih santai dan tidak terbebani dengan tuntutan untuk menguasai tari secara teoritis tentu saja dapat menjebak anggota dalam situasi yang salah.

Kondisi yang berefek negatif ini dapat dihindari dengan adanya penyesuaian diri sanggar dengan mempertimbangkan kondisi anggota yang masih berstatus pelajar dengan membekali keterampilan tari dengan baik, sebab sanggar sangat berpeluang untuk melakukan hal ini mengingat sanggar memang lebih banyak berkutat dalam pelatihan terlebih bagi sanggar yang melaksanakan pelatihan rutin bagi anggotanya. Selain itu permintaan untuk mengisi acara dewasa ini meningkat sehingga terkadang frekwensi sanggar melakukan pertunjukan terbilang tinggi, hanya saja dibutuhkan kesediaan dan kesadaran dari pemilik sanggar untuk terus mengasah kemapuan dan keterampilan anggotanya secara benar dan baik.

Profil sanggar juga akan berdampak pada rekrutmen anggota yang bisa saja akan terus bertambah dengan munculnya figur anggota sanggar yang juga sukses dalam pendidikannya, situasi ini tentu saja akan menjadi pertimbangan mahasiswa dalam memilih sanggar yang menurut mereka bermutu ditengah menjamurnya sanggar di kota Makassar.

\section{Proses}

Pelatihan dalam sanggar-sanggar seni yang tumbuh di masayarakat ditingkatkan dan diarahkan untuk menghasilkan karya seni yang bermutu dalam rangka memperkaya aset budaya bangsa, oleh karena itu membutuhkan sinergi antara pemilik, instruktur, dan anggota sebab kegiatan ini melibatkan bagaimana pemilik dan instruktur mengembangkan kreativitasnya, dan anggota dapat melatih dan mengembangkan kemampuan dalam hal keterampilan olah geraknya.

Keterampilan olah gerak mahasiswa yang tergabung dalam sanggar tari sejatinya tidak diragukan lagi, hanya yang perlu menjadi pertimbangan antara kesesuaian kemampuan ketika berada disanggar dan dalam mengaplikasikan kemampuan tersebut ketika berada dikampus, khususnya dalam hal olah gerak. mengingat sanggar dan kampus berbeda orientasi, sanggar lebih ke komoditi sementara di kampus menyesuaikan dengan kebutuhan kurikulum. Dan untuk menyikapi hal ini perlu kecermatan dari mahasiswa yang tergabung disanggar untuk lebih memanfaatkan peluang yang diberikan oleh sanggar untuk mengesplorasi kemampuannya sebaik mungkin. Sebab sanggar lebih memberi peluang untuk mempelajari berbagai jenis bentuk tari didukung oleh frekwensi untuk melakuan pertunjukan lebih sering tentu saja dengan sendirinya mendukung mahasiswa untuk lebih mahir dalam mengolah keterampilan geraknya.

Pada proses pelatihan disanggar, peserta biasanya dibekali dengan berbagai macam jenis tari daerah setempat, dan hal ini 
tentu saja dapat berpengaruh pada keterampilan mahasiswa dalam hal menarikan tari daerah setempat karena biasanya dikampus tari daerah yang diberikan terbatas karena karena harus menyesuaikan dengan kepentingan kurikulum sementara disanggar tidak dibatasi oleh apapun, sehingga secara skill akan menkjadi lebih baik, dan selanjutnya anggota diberi ruang untuk mengembangkan tari, sebab sanggar menampilkan tari sesuai dengan riquest atau pesanan pemakai jasa, dan ini dapat berefek pada pengasahan kemampuan di bidang koreografi, sehingga mahasiswa yang tergabung dalam sanggar tidak menemui kendala ketika mendapat tugas untuk menata atau menciptakan tari sendiri.

Ada beberapa pemilik sanggar di kota Makassar yang tidak memiliki basic tari hanya bisa dan menyukai dunia seni tari, namun memiliki modal yang cukup untuk mendirikan dan mendanai operasional sanggar. Dan, kondisi ini merupakan peluang besar bagi mahasiswa tari untuk mengaplikasikan dan mengembangkan ilmunya dengan baik. Dalam setiap proses adanya suatu kendala adalah satu hal yang wajar dan dialami oleh setiap sanggar. Kendala tersebut bisa saja muncul dari pelatih yang memiliki tanggung jawab lain ataupun dari anggota yang memiliki aktivitas lain. Namun, hal ini dapat diatasi dengan kepatuhan pada komitmen yang telah disepakati bersama dan telah menjadi aturan setiap sanggar.

\section{Presatasi Mahasiswa yang Tergabung Dalam Sanggar}

Prestasi mahasiswa yang tergabung dalam sanggar ditandai dengan banyaknya mahasiswa yang sering menjuarai lomba tari yang dilaksanakan oleh instansi lain, dan ini juga nampak pada nilai ujian dalam hal praktek atau keterampilan olah gerak dalam menarikan suatu tarian, serta menata atau menciptakan tari kreasi baru. Hal ini tidak terlepas dari peran sanggar yang telah memberi ruang bagi mahasiswa tari yang tergabung sebagai anggota sanggar untuk berkreativitas.

Prestasi mahasiswa yang tergabung dalam sanggar sangat nampak pada Keterampilan olah gerak mahsiswa dalam menarikan sebuah tari, baik secara teknik maupun hafalan. Selain itu kemampuan mahasiswa yang tergabung dalam sangar juga tergambar pada saat proses penggarapan sebuah karya tari yang menjadi tugas pada salah satu mata kuliah, mahasiswa yang tergabung dalam sanggar lebih cermat dan mampu menggarap lebih baik, walau demikian bukan tanpa kendala khususnya dalam hal membagi waktu antara menjalankan aktivitas sanggar dan kampus. Namun kondisi ini jika dapat diatur dan diatasi dengan baik tentu saja tidak akan menjadi persoalan, dan sejauh ini mahasiswa pada Prodi Seni Tari dapat mengatasi masalah tersebut sehingga sebagaian besar mahasiswa yang tergabung dalam sanggar dapat selasai tepat waktu dengan nilai yang baik dan memuaskan.

Efek kehadiran sanggar pada prestasi mahasiswa sesungguhnya beragam, ada yang berprestasi baik namun ada pula yang kurang baik, hal ini terjadi lebih banyak disebabkan oleh personaliti. Seharusnya hal tersebut tidak terjadi sebab keterampilan olah gerak seseorang akan terasah dengan sendirinya dengan latihan yang rutin dan hal ini dapat terpenuhi di sanggar mengingat jadwal pertunjukan sanggar tergolong berintensitas tinggi, hanya saja terkadang ada beberapa sanggar yang kurang memperhatikan dari sisi teknik gerak penari. Namun pada sanggar yang menjadwalkan pelatihan rutin hal tersebut tentu saja tudak terjadi, terlebih pada sanggar yang memang lebih fokus pada pelayanan jasa pelatihan atau kursus.

\section{KESIMPULAN DAN SARAN}

\section{A. Kesimpulan}

Sanggar tari merupakan pusat dari kegemilangan seni dan moral, maka sudah seyogyanya diperhatikan dan dimanfaatkan segala potensi termasuk mewujudkan fungsi sanggar secara maksimal serta melatih skill penari dengan baik, sebab bila area ini dioptimalkan, dapat dipastikan penari hiburan, penari profesional, dan seniman tari akan 'hadir' serta akan berdampak pada prestasi mahasiswa yang dengan sendirinya akan memicu bermunculannya seniman tari intelektual.

\section{B. Saran}

Berdasarkan kesimpulan tersebut diatas, maka dapat disarankan beberapa hal sebagai berikut:

1. Agar dapat mengoptimalkan peran sanggar sebagai pelestari seni tari baik tradisi maupun kreasi dan dapat berkontribusi pada prestasi mahasiswa yang tergabung dalam sanggar.

2. Diharapkan dapat menjadi pertimbangan bagi sanggar dalam merencanakan 
Rahma, M, Peningkatkan Keterampilan Olah Gerak Yang Kontributif terhadap prestasi mahasiswa Prodi Seni Tari Dengan Optimalisasi Peranan Sanggar Tari, hlm. 36-43

kegiatannya sehingga sanggar tidak hanya berkontribusi dari sisi ekonomi tetapi dapat juga berkontribusi bagi prestasi mahasiswa yang tergabung dalam sanggar.

3. Perlu ada kerjasama yang baik antara pemilik sanggar, instruktur, dan anggota sanggar dalam menjalankan fungsi masingmasing terlebih ketika ada salah satu pihak yang memiliki tanggung jawab lain sehingga semua fungsi dapat berjalan dengan baik terlebih bagi mahasiswa yang masih memiliki tanggung jawab dengan tugas-tugas kampus.

\section{Daftar Pustaka}

Arif, Ahmad. Besi Luwu, Pasang Surut Astini, Dewi, 2007, Bedha Jurnal Surya Seni Penciptaan dan Pengkajian Seni ISI Yogyakarta, Yogyakarta

Hadi, Sumadiyo Y, 2011, Koreografi BentukTeknik-Isi, Yogyakarta; Multi Grafindo

Jazuli, M, 2014, Paradigma Pendidikan Seni, Semarang; Farishma Indonesia

Langer, Zusanne K, Terjemahan FX. Widaryanto, 2006, Problematika Seni, Bandung; Sunan Ambu Press

Murgiyanto, Sal, 2004, Tradisi dan Inovasi, Jakarta; Wedatamawidya Sastra

Peursen, Van C.A, 1988, Strategi Kebudayaan terjemahan dari buku Cultuur In Stroomversnelling oleh Dick Hartoko, Yogyakarta; Kanisius

Soedarsono, 1986, Elemen-Elemen Dasar Komposisi Tari Terj. Dari Buku Dances Composition The Basic Elemen oleh La Mery, ISI Yogyakarta: Lagaligo 
Jurnal Pakarena, Volume 4 Nomor 1, Juni 2019 